\title{
Metode Konseling dalam Membantu Mengurangi Kecanduan Rokok pada Karyawan Politeknik Kesehatan Kemenkes Pangkalpinang
}

\author{
Syamsul Rizal Sinulingga \\ Jurusan Farmasi, Politeknik Kesehatan Pangkal Pinang, Indonesia \\ Email: rizalsinulingga@yahoo.com
}

\begin{abstract}
Counseling Methods in Helping Reduce Cigarette Addiction in Employees Politeknik Kesehatan Kemenkes Pangkalpinang. Indonesia is the country with the third largest number of smokers around the world about 65 Milion people. This count will be increased if the government not make rules for the smoker and tobacco industries and do not application avoid of advertisement of tobacco. Until now Indonesia was the third position as the country with largest tobacco consumers around the world, with approximately more than 225 billion cigarettes per years, above Chine and India, or almost half the smoker of ASEAN. The Province of Bangka Belitung according to the fact become the highest smoker in Indonesia. Every day about 18,3 million cigarettes were consumed by the Bangka Belitung people, it became the highest count in Indonesia, a then the lower in Yogyakarta. This research aimed to know the effectiveness of counseling method to helping decrease smoke behavior about Poltekkes Pangkalpinang Employees. This research was used pre-experiment with one group pre-test and post-test design. All of research subject sample about 14 persons with an active smoker with variations of length since minimum about 4 years and maximum 34 years. The mean value of frequency distribution before counseling was 15,57 pc/day. Measurement after counseling decreased till 12,72 pc/day. Comparison statistic test showed that value about 0,065 , then Ho un-acceptance and that mean occurring differently about smoke behavior between before and after counseling. Occurring different about smoke behavior between before and after counseling implement.
\end{abstract}

Keywords: Smoke behaviour, Cigarette

Abstrak: Metode Konseling dalam Membantu Mengurangi Kecanduan Rokok pada Karyawan Politeknik Kesehatan Kemenkes Pangkalpinang. Indonesia merupakan jumlah perokok terbanyak ketiga didunia yaitu sekitar 65 juta orang, dengan konsumsi lebih dari 225 miliar batang per tahun, di bawah Cina dan India atau hampir setengah (46\%) perokok ASEAN. Provinsi Bangka Belitung (Babel) ternyata menjadi juara dalam hal merokok se-Indonesia. Setiap hari sebanyak 18,3 batang rokok dihisap oleh masyarakat Babel, yang menjadi angka tertinggi di Indonesia. Tujuan penelitian ini adalah untuk mengetahui efektifitas metode konseling dalam membantu mengurangi perilaku merokok karyawan Poltekkes Pangkalpinang. Penelitian ini merupakan penelitian pra eksperimen dengan menggunakan rancangan one group pre-test and post-test design. Responden sebanyak 14 orang merupakan perokok aktif dengan durasi waktu yang bervariasi dari yang terendah adalah 4 tahun dan tertinggi adalah 34 tahun. Nilai mean distribusi frekuensi jumlah rokok sebelum konseling adalah sebesar 15,57 batang/hari. Pengukuran setelah dilaksanakan konseling jumlahnya terdapat penurunan menjadi 12,71 batang/hari. Hasil uji perbedaan mean menunjukkan nilai sebesar 0,065 lebih besar dari alfa 0,05 , sehingga dapat dimaknai tidak terdapat perbedaan perilaku merokok sebelum dan sesudah dilaksanakan konseling.

Kata kunci: Perilaku merokok, Rokok

Merokok merupakan suatu kebiasaan yang sudah lazim dilakukan oleh semua orang. Menurut analisa harian surat kabar Kompas (2012), Indonesia merupakan jumlah perokok terbanyak ketiga didunia sekitar 65 juta orang. Angka ini akan terus meningkat jika pemerintah tidak mengatur perilaku merokok dan industri rokok serta tidak menerapkan larangan iklan rokok. Banyak studi yang dilakukan oleh akademisi yang mengemukakan bahaya merokok bagi kesehatan.

Saat ini Indonesia menempati urutan ke-3 sebagai negara konsumen rokok tertinggi di dunia dengan konsumsi lebih dari 225 miliar 
batang per-tahun, di bawah Cina dan India atau hampir setengah $(46 \%)$ perokok ASEAN. Prevalensi perokok pada usia 13-15 tahun, 24,5\% laki-laki dan 2,3\% perempuan dari total populasi Indonesia (Antara_News, 2012).

Menurut informasi Provinsi Bangka Belitung (BKD_Babel, 2015), bahwa Provinsi Bangka Belitung (Babel) ternyata menjadi juara dalam hal merokok se-Indonesia. Setiap hari sebanyak 18,3 juta batang rokok dihisap oleh masyarakat Babel, yang menjadi angka tertinggi di Indonesia, dan terendah di Yogyakarta.

Banyak cara yang dapat dilakukan untuk dapat mengurangi keinginan untuk berhenti merokok. Mulai dari mengkonsumsi obat-obatan, dengan cara hipnoterapi hingga dengan berbagai metode lain yang dapat mempengaruhi perilaku. Salah satunya adalah dengan metode konseling yang bermanfaat untuk membantu mengurangi kecanduan merokok.

Konseling atau penyuluhan adalah pemberian bantuan oleh konselor kepada konseli sedemikian rupa sehingga pemahaman terhadap kemampuan diri sendiri meningkat dalam memecahkan berbagai masalah (KBBI, 2013).

Konseling adalah proses yang melibatkan hubungan antar pribadi antara seorang terapis dengan satu atau lebih konseli dimana terapis menggunakan metode-metode psikologis atas dasar pengetahuan sistematik tentang kepribadian manusia dalam upaya meningkatkan kesehatan tentang kepribadian manusia (Petterson, 1996). Konseling bisa dilakukan dalam berbagai bidang kehidupan, seperti di masyarakat, di dunia industri, membantu korban bencana alam, maupun di lingkungan pendidikan, serta kesehatan. Khusus pada dunia kesehatan, konseling sudah diterapkan pada berbagai bidang diantaranya adalah kebidanan, keperawatan dan kefarmasian.

\section{METODE}

Jenis penelitian yang dilakukan adalah Pra Eksperimen dengan menggunakan rancangan one group pre-test and post-test design. Menurut Sugiyono (2010), penelitian Pra Eksperimen adalah penelitian eksperimen yang hanya mempergunakan kelompok eksperimen saja tanpa kelompok kontrol (pembanding). Sampel subjek dipilih seadanya tanpa mempergunakan randomisasi. Analisis data menggunakan teknik komparasi dua sampel yang saling berkaitan menggunakan uji T-Test sampel berkorelasi.

Populasi penelitian adalah seluruh karyawan yang memiliki perilaku merokok aktif sebanyak 14 karyawan laki-laki. Sampel diambil secara total sampling, pelaksanaan penelitian di Poltekkes Kemenkes Pangkalpinang.

\section{HASIL}

Subjek penelitian yang berpartisipasi adalah karyawan Poltekkes Pangkalpinang yang berjumlah 14 (empat belas) orang.

Tabel 1. Distribusi Lama Merokok Responden

\begin{tabular}{ccrr}
\hline $\begin{array}{c}\text { Jml } \\
\text { Rokok }\end{array}$ & Frekuensi & \% & \multicolumn{2}{c}{ \%umulatif } \\
\hline 4 & 1 & 7.1 & 7.1 \\
5 & 1 & 7.1 & 14.3 \\
8 & 1 & 7.1 & 21.4 \\
10 & 3 & 21.4 & 42.9 \\
15 & 3 & 21.4 & 64.3 \\
16 & 1 & 7.1 & 71.4 \\
17 & 2 & 14.3 & 85.7 \\
20 & 1 & 7.1 & 92.9 \\
34 & 1 & 7.1 & 100.0 \\
Total & 14 & 100.0 & 100.0 \\
\hline
\end{tabular}

Pada tabel 1 menunjukkan bahwa sebagian besar responden berada pada durasi 10 hingga 17 tahun menjadi perokok aktif. Batas bawah dari merokok tersebut adalah selama 4 tahun dan yang paling lama adalah 34 tahun.

\begin{tabular}{ccrr} 
Tabel 2. Distribusi & \multicolumn{2}{c}{$\begin{array}{c}\text { Perilaku } \\
\text { Responden }\end{array}$ Sebelum Konseling } \\
\hline $\begin{array}{c}\text { Jml } \\
\text { Rokok }\end{array}$ & Frekuensi & \multicolumn{2}{c}{ Merokok } \\
\hline 6 & 2 & 14.3 & \multicolumn{2}{c}{ Kumulatif } \\
8 & 1 & 7.1 & 14.3 \\
10 & 3 & 21.4 & 42.9 \\
16 & 5 & 35.7 & 78.6 \\
20 & 1 & 7.1 & 85.7 \\
32 & 1 & 7.1 & 92.9 \\
36 & 1 & 7.1 & 100.0 \\
Total & 14 & 100.0 & \\
\hline
\end{tabular}

Jumlah rokok yang dikonsumsi semakin besar yaitu mulai dari yang terendah sebanyak 2 batang hingga yang terbanyak sejumlah 32 batang, dengan rata-rata jumlah rokok yang dikonsumsi responden adalah 12,71 batang/hari. 
Tabel 3. Perbedaan Mean Jumlah Rokok Sebelum Dan Sesudah Konseling

\begin{tabular}{cccrr}
\hline & Mean & $\mathrm{n}$ & $\begin{array}{c}\text { Std. } \\
\text { Deviation }\end{array}$ & $\begin{array}{c}\text { Std. Error } \\
\text { Mean }\end{array}$ \\
\hline $\begin{array}{c}\text { Sebelum } \\
\text { konseling }\end{array}$ & 15.57 & 14 & 8.950 & 2.392 \\
$\begin{array}{c}\text { Sesudah } \\
\text { konseling }\end{array}$ & 12.71 & 14 & 7.750 & 2.071 \\
\hline
\end{tabular}

Tabel 3 menunjukkan terdapat perbedaan rata-rata jumlah rokok sebelum dan sesudah konseling dengan kecenderungan berkurang dari 15,57 menjadi 12,71 batang rokok yang dihisap responden setiap hari.

Tabel 4. Hubungan Perilaku Merokok Sebelum Dan Sesudah Konseling

\begin{tabular}{lcccc}
\hline & & n & Correlation & Sig. \\
\hline $\begin{array}{l}\text { Sebelum } \\
\text { konseling }\end{array}$ & $\&$ & & & \\
$\begin{array}{l}\text { Sesudah } \\
\text { konseling }\end{array}$ & & 14 & .808 & .000 \\
\hline
\end{tabular}

Setelah dilakukan uji komparasi dari 14 responden, didapatkan nilai siginfikansi 0,00 , dengan aturan jika sig<0,05 maka bermakna ada hubungan jumlah rokok yang dikonsumsi oleh responden sebelum dan sesudah dilaksanakan konseling. Terlihat sumbangan konseling terhadap perubahan jumlah rokok yang dikonsumsi sebesar $0,808^{2}=0,62$. Dari nilai tersebut berarti $62 \%$ penurunan jumlah rokok dikarenakan konseling, dan sisanya karena faktor lain.

Tabel 5. Perbedaan Jumlah Rokok Sebelum Dan Sesudah Konseling

\begin{tabular}{|c|c|c|c|c|c|c|}
\hline & \multicolumn{5}{|c|}{ Paired Differences } & \multirow{3}{*}{$d f$ Sig. } \\
\hline & \multirow[t]{2}{*}{ Mean } & \multirow[t]{2}{*}{$\begin{array}{c}\text { Std. } \\
\text { Dev. }\end{array}$} & \multirow[t]{2}{*}{$\begin{array}{l}\text { Std. } \\
\text { Error } \\
\text { Mean }\end{array}$} & \multicolumn{2}{|c|}{$\begin{array}{c}95 \% \\
\text { Confidence } \\
\text { Interval }\end{array}$} & \\
\hline & & & & Lower & Upper & \\
\hline $\begin{array}{c}\text { Sebelum } \\
\text { konseling } \\
\text { - Sesudah } \\
\text { konseling }\end{array}$ & 2.857 & 5.304 & 1.418 & -.205 & 5.920 & 2.01613 .065 \\
\hline
\end{tabular}

Berdasarkan dari tabel 5 menunjukkan nilai signifikansi sebesar 0,065 . Dengan demikian nilai $p \quad 0,065>0,05$ pada taraf signikansi $5 \%$, maka tidak terdapat perbedaan perilaku merokok responden sebelum dan sesudah dilaksanakan konseling.

\section{PEMBAHASAN}

\section{Riwayat Lama Merokok}

Berdasarkan data yang diperoleh, sebagian besar responden berada pada rentang 10 sampai dengan 17 tahun menjadi perokok. Hal ini menunjukkan bahwa umumnya responden telah merokok dalam jangka waktu yang lama. Ini terlihat dari pengakuan responden yang mengatakan jika mereka merokok bahkan sejak dari bangku sekolah menengah atas.

Penelitian membuktikan bahwa perilaku merokok menjadi tren di kalangan pelajar khususnya tingkat menengah atas. Berdasarkan penelitian Prasetyawan (2016) menunjukkan bahwa sebagian besar responden merupakan perokok dengan klasifikasi ringan dan menengah. Faktor yang mempengaruhi adalah akibat lingkungan dan pergaulan sehingga ikut-ikutan menjadi perokok.

Dampak rokok memang akan terasa setelah 10-20 tahun pasca penggunaan. Rokok juga punya dose-response effect, artinya semakin muda usia mulai merokok, semakin sulit untuk berhenti merokok, maka semakin lama seseorang akan memiliki kebiasaan merokok (Setyanda, 2015).

Akibat dampak merokok yang bersifat lama tersebut menyebabkan seseorang yang menjadi perokok merasa bahwa rokok belum menyebabkan gangguan kesehatan seperti yang tercantum pada label peringatan kemasan rokok. Responden memiliki asumsi bahwa masalah kesehatan yang menimpa pada seseorang perokok dapat dipengaruhi berbagai faktor selain rokok itu sendiri.

Menurut Herlina (2008), umumnya perokok adalah kaum laki-laki yang dipengaruhi oleh berbagai rangsangan eksternal seperti pengaruh lingkungan, harga diri dan kejantanan.

\section{Perilaku Merokok Sebelum Konseling}

Data menunjukkan bahwa sebagian besar (35.6\%) responden menghabiskan rokok dalam sehari sebanyak 16 batang, disusul kemudian sebanyak 10 batang/hari (14,3\%). Hal ini setara dengan konsumsi rata-rata harian rokok responden adalah satu bungkus dalam setiap hari, dengan asumsi dalam kemasan sebungkus rokok terdiri dari 10-16 batang.

Dahulu perilaku merokok disebut sebagai suatu kebiasaan atau ketagihan, tetapi dewasa ini merokok dapat didefinisikan sebagai perilaku penggunaan tembakau yang menetap, biasanya lebih dari setengah bungkus rokok per hari, 
dengan adanya tambahan distres yang disebabkan oleh kebutuhan akan tembakau secara berulangulang. Perilaku merokok dapat juga didefinisikan sebagai aktivitas subjek yang berhubungan dengan perilaku merokoknya, yang diukur melalui intensitas merokok, waktu merokok, dan fungsi merokok dalam kehidupan sehari-hari (Helmi, 2000).

Selain sebagai inisiasi atau jalan ke kedewasaan, merokok bagi pria juga akhirnya menjadi semacam trademark atau ciri seorang laki-laki. Setiap rumah pun hampir selalu menyediakan asbak rokok karena yakin 100\% para tamu pria pasti merokok (Priyatin, 2009).

\section{Perilaku Merokok Sesudah Konseling}

Perubahan rentang jumlah rokok yang dikonsumsi semakin memiliki kesenjangan yaitu dari yang terendah sebanyak 2 batang hingga yang paling banyak mengkonsumsi yaitu 32 batang. Namun sebagian besar respsonden masih mengkonsumsi rokok hingga 16 batang/hari sebanyak $28,6 \%$. Belum ada satu pun responden yang berhenti merokok sesudah dilaksanakan konseling.

Individu yang memiliki pusat kendali eksternal mengalami kesulitan dalam membuat keputusan terkait dengan pemenuhan kebutuhan mereka, tidak memiliki pandangan yang jelas tentang masa depan atau kurang mampu mengintegrasikan fakta dan ide-ide baru (Chotidjah, 2012).

Pusat kendali kesehatan merupakan salah satu faktor yang menentukan perilaku kesehatan dan secara tidak langsung menentukan status sehat seseorang. Dengan kata lain, pusat kendali Kesehatan dimediasi oleh perilaku kesehatan yang akan mempengaruhi status kesehatan orang tersebut. Hal ini terjadi karena keyakinan ini telah dipelajari selama mereka hidup dan menjadi status kesehatan mereka pada masa lalu dan juga pengalaman kesehatan yang bersifat pribadi dan nyata (Sarafino, 1998).

\section{Uji Perbedaan Perilaku Merokok}

Hasil pengujian menunjukkan nilai 0,065 pada taraf signifikansi 5\%, yang bermakna tidak terdapat perbedaan perilaku merokok sebelum dan sesudah dilaksanakan konseling. Meskipun pada tabel 5 menunjukkan perubahan jumlah rata-rata jumlah rokok yang dikonsumsi menunjukkan penurunan, namun setelah dilakukan uji beda tidak terdapat perbedaan yang bermakna sebelum dan sesudah dilaksanakan konseling.
Seseorang yang berasal dari keluarga konservatif yang menekankan nilai-nilai sosial dan agama dengan baik dengan tujuan jangka panjang lebih sulit untuk terlibat dengan rokok, tembakau, obat-obatan dibandingkan dengan keluarga yang permisif, dan yang paling kuat pengaruhnya adalah bila orang tua sendiri menjadi figur contoh yaitu sebagai perokok berat, maka anak-anaknya akan mungkin sekali untuk mencontohnya (Priyatin, 2009).

Penelitian Rahman (2015) menunjukkan bahwa teknik konseling berkelompok dapat membantu mengurangi secara signifikan perilaku merokok siswa SMU. Untuk merubah perilaku merokok berhenti total masih sangat sulit mengingat banyak faktor yang mempengaruhi usaha tersebut. Namun dengan mengurangi kebiasaan merokok merupakan fungsi pengentasan, karena layanan bimbingan dan konseling dapat berfungsi sebagai pengentasan atau perbaikan artinya fungsi bimbingan dan konseling akan menghasilkan pemahaman tentang sesuatu oleh pihak-pihak tertentu sesuai dengan kepentingan subyek penelitian.

Hal ini sesuai dengan penelitian Prasetyawan (2016) yang menunjukkan bahwa tindakan konseling yang diberikan kepada siswa SMU efektif meningkatkan tindakan responden terhadap bahaya rokok. Dalam penelitian tersebut diketahui bahwa terjadi perubahan perilaku lebih positif tentang bahaya rokok dengan mengurangi jumlah rokok, tidak berkumpul dengan komunitas perokok dan menyadari tentang dampak kesehatan yang ditimbulkan oleh rokok.

\section{SIMPULAN}

Berdasarkan hasil penelitian maka dapat disimpulkan bahwa upaya membantu berhenti merokok karyawan Poltekkes Pangkalpinang menunjukkan tidak terdapat perbedaan perilaku merokok responden sebelum dan sesudah dilaksanakan konseling.

\section{SARAN}

Dibutuhkan waktu yang lebih lama dalam proses perubahan dan pengamatan upaya berhenti merokok. Serta sangat dibutuhkan ruang khusus/karantina agar proses perubahan perilaku responden tidak terpengaruh faktor pengganggu seperti lingkungan, teman sebaya, dan lain sebagainya 


\section{DAFTAR PUSTAKA}

Antara News. 2012. Beranilah Melawan Perokok.

http://www.antaranews.com/print/13067 93040/beranilah-melawan-perokok.

BKD Babel. 2015. Babel Angka Perokok Tertinggi di Indonesia Translate. http://bkd.babelprov.go.id/content/babel -angka-perokok-tertinggi-di-indonesiatranslate.

Chotidjah, S. 2012. Pengetahuan Tentang Rokok, Pusat Kendali Kesehatan Eksternal Dan Perilaku Merokok. Makara, Sosial Humaniora Jurusan Psikologi, Fakultas Ilmu Pendidikan, Universitas Pendidikan Indonesia, Bandung, Vol. 16.

Helmi, K. 2000. Faktor-faktor Penyebab Perilaku Merokok pada Remaja. Jurnal Psikologi, 27(1), 37-47.

Herlina, Siti Rahmalia HD, dan Yulia Irvani Dewi. 2008. Hubungan Riwayat Merokok dengan Stadium Kanker Paru. [Skripsi]. Unviersitas Riau.

Kamus Besar Bahasa Indonesia. 2013. Konseling. https://kbbi.web.id/konseling.

Kompas. 2012. Perokok Indonesia Terbesar Ketiga Dunia. http://regional.kompas.com/read

Petterson, C. . 1966. Theories of Counseling and Psychotherapies. New York: Harper
\& Row Publisher.

Prasetiawan, P., Sakka, A., \& Erawan, P. E. M. 2016. Efektivitas Metode Konseling terhadap Perilaku Merokok pada Siswa SMA di Kecamatan Laeya Tahun 2015. Jurnal Ilmiah Mahasiswa Kesehatan Masyarakat, 1(2).

Priyatin, B. 2009. Pengaruh Fungsi Keluarga Terhadap Perilaku Merokok Remaja Di Desa Waluyorejo Kecamatan Puring Kabupaten Kebumen. Jurnal Ilmiah Kesehatan Keperawatan Jurusan Keperawatan Stkes Muhammadiyah Gombong, Volume 5.

Rahman, H., Giyono Giyono, Ratna Widiastuti. 2015. Penggunaan Layanan Konseling Kelompok dalam Mengurangi Perilaku Merokok Siswa Kelas X. ALIBKIN, Jurnal Bimbingan dan Konseling. Vol 4, No 2.

Sarafino. 1998. Health psychology, biopsychosocial interaction. TC Systems, Inc.

Setyanda, Y. O. G., Sulastri, D., \& Lestari, Y. 2015. Hubungan merokok dengan kejadian hipertensi pada laki-laki usia 35-65 tahun di Kota Padang. Jurnal kesehatan andalas, 4(2).

Sugiyono, D. 2010. Metode penelitian Kuantitatif Kualitatif dan $R \& D$. Jakarta: Alfabeta. 